\title{
NON-KEYNESIAN EFFECTS OF FISCAL DISCIPLINE: A COMPUTABLE GENERAL EQUILIBRIUM ANALYSIS FOR TURKEY*
}

\author{
Murat ASLAN ${ }^{* *}$
}

\section{Özet}

$\mathrm{Bu}$ makalenin amacı en son hazırlanan verileri kullanarak, analitik bir araç olan hesaplanabilir denge model yöntemi ile, Türkiye için dinamik bir model dizayn etmektir. $\mathrm{Bu}$ model alternatif varsayımlar altında, devletin sıkı maliye politikalarının sonucları üzerine simülasyonlar yapmıştır. Modelimiz devletin sıkı maliye politikasının güvenilir olması durumunda bunun toplumun tüm kesimlerinde pozitif bir gelir artışı olarak hissedileceğini tespit etmiştir.

Anahtar Kelimeler: Hesaplanabilir denge modeli, maliye politikas1, kapasite kullanımı, Türkiye ekonomisi.

\section{Abstract}

By using the most recent data, the objective of this study is to build a dynamic computable general equilibrium (CGE) model for Turkey. By employing alternative assumptions on alternative fiscal austerity measures undertaken by government, the model conducts some simulations. In regard to the possible effects of a fiscal austerity program with a varying degree of credibility, our CGE model shows that fiscal discipline with significant credibility ensures positive income effects, and all layers of the society would benefit from this outcome.

Keywords: CGE, fiscal policies, capacity utilization, Turkish economy.

\footnotetext{
* This research is based on a part of the author's dissertation. The author would like to thank D. Houser, K. McCabe, D. Porter, and other scholars at the James Buchanan Center and ICES at the George Mason University for their valuable comments and also thank to D. Houser and ICES for their financial contribution for this research. The author would like to thank to S. Robinson and Hans Lofgren and other scholars at the IFPRI at the Washington DC for their help in model algorithm and GAMS programming. The early draft of this project is presented at the Easter Economic Association Conference, Washington DC, on November, 2003 and also extended version of the first draft was also presented at the seminar at Hacettepe University, Ankara. We would like to thank the conference and seminar participants for their valuable comments. Usual disclaimer is applied.

** Dr., Osmangazi Üniversitesi İktisadi ve İdari Bilimler Fakültesi
} 


\section{Introduction}

Building an applied economic model involves introducing a set of equations which describe the relationships among the variables. Those equations represent an interpretation of the links among the economic actors i.e., households, firms, government for a particular subject over which a researcher is trying to address some of the questions that might be explained through such modeling effort. In order to shed some lights over some macro and micro issues in Turkish economy in recent years, we build an applied computable general equilibrium model for the Turkish economy. The objective of this essay is to explain our interpretation of the economic problems in the Turkish economy through using set of equations which might explain the links among the economic actors and their respective economic actions.

The model differs from other CGE models for at least two reasons. Firstly, the model proposes alternative functional forms reflecting the importance of supply-side response in the creation of the business cycles. In particular, different from other structural models which are parallel to Keynesian tradition i.e. fiscal policy shocks is transmitted into economy through variables related to demand side of the economy, this model elucidates the adverse effect of budget deficits on variables related to supply side of the economy. In fact, the main inspiration of this research regarding the importance of the supply shocks is based on empirical evidences for Turkish economy for the last two decades. In order to connect the stylized supply-shocks into the CGE model, we hypothesize that the capacity utilization does not necessarily depend on the monopolistic market structure (as in the other structural CGE models), but correlates with supply of funds in the financial markets. Since the model does not incorporate the financial variables, we hypothesize that the budget deficits adversely affect firms in borrowing from financial markets for their working capital needs through their direct effects over capacity utilization. Intuitively, there are at least two explanations regarding adverse effects of credit-squeeze and high real interest rates on capacity utilization. Firstly, as the available funds are mainly directed to finance budget deficits, the credit-squeeze will adversely affect firms to borrow from financial markets for their short term credit needs. In 
particular, the evidences ${ }^{1}$ show that when Turkish economy faces an interest shock (i.e. increase in interest rates), banks significantly reduce their loans loan to small and medium size firms which generally depend on these loans in financing their working capital. Secondly, a research shows that during the last decade, high real interest rates offered by government securities became more attractive source of profit than profit generated from real sector related activities. In particular, according to survey-based report by the Istanbul Chambers of Commerce in 1997, more than 50 percent of gross profits of Turkey's top 500 industrial companies came from interest earnings (Istanbul Sanayi Odasi, 1998: p. 86). Combining these two effects (i.e. credit squeeze which significant adverse effects on small and medium size firms and the high real interest rates which encouraged large firms in real sectors to concentrate on financial activities), this research offers a simple model regarding supplyside response of Turkish economy to undisciplined fiscal policies. Second modification of this model is to use of the most recent data. One of the most important data set for building CGE model is the social accounting matrix (SAM). The most recent SAM was constructed by Aslan (2004), and the model employs this data set.

This essay is divided into four sections. In the first section, we will provide a brief literature review over the importance of supply shocks in the business cycle. In the second section, we will give a detailed explanation over the CGE model we built for this research. In the third section, we will discuss the base solution for the model and we will focus on the counterfactual experiments that we run using our calibrated model through changing some of the policy parameters. The chapter will end with conclusions and a layout of future research objectives. Before going into the detail of the model, it is useful to remind that no model can be expected to reflect real life in its minutest details. Obviously, any modeling exercise is but only a gross approximation of reality, with a more detailed focus on the most significant variables, leaving secondary variables outside the model's coverage.

\footnotetext{
${ }^{1}$ See for example Erkumay (2000), Sariaslan (1994) and Yörük (2002) for the adverse effects of credit squeeze on small and medium size firms.
} 


\section{Capacity Utilization and the Supply-Side Factors of Business Cycle}

The importance of supply-side variables in business cycles is introduced by Real-Business Cycle literature e.g. Prescott (1986), Kyndland and Prescot (1982), and Long and Plosser (1983). The importance of capacity utilization as an important variable in explaining pro-cyclical productivity is explored by Burnside et al. (1995) and Fay et al. (1985). Agenor et al. (2000) in their empirical study on business cycle regularities in developing countries including Turkey shows that the observed pattern of pro-cyclical behavior of real wages and countercyclical behaviors of both price level and inflation suggest that supplyshocks may have been playing significant role in macroeconomic fluctuations during the last two decades for Turkish economy.

Given the importance of the supply side variables in generation of business cycles in Turkey, we investigated feasible mechanisms which are consistent with both Turkish business cycle regularities and CGE framework. Among several variables, during the last decade, we observe both that capacity utilization has displayed significant pro-cyclical pattern and that the capacity utilization has been very sensitive to available funds supplied by banking sector to private sector. One method to reproduce the effects of credit over production is the inclusion of working capital requirement and assuming that firms need loans not only for investment purposes, but also for their working capital needs ${ }^{2}$. Naastepad (2002) argues that even if aggregate working capital needs financing from retained earnings of the firms, on the micro level each firm faces fluctuations in the need for working capital that can only be met with access to short term credit. When available funds are largely used for financing government deficits, the supply of loans left for the private sector is likely to decline and, therefore, the credit squeeze due to adverse fiscal shocks might reduce the amount of credit available to the private sector and thus reduce the capacity utilization ${ }^{3}$.

\footnotetext{
${ }^{2}$ The importance of working capital in the Turkish economy, particularly for the small and medium size enterprises, is studied by Sariaslan (1994) and Sariaslan (1996). Yörük (2002) shows that in response to interest shocks in the financial markets firms tend to not only reduce their investment spending, but also cut their average costs through reducing their capacity.

${ }^{3}$ The effects of fiscal and political variables over macroeconomic performance are also examined in the literature. In particular, Alesina et al. (1995) showed that there is negative correlation between political instability (frequent government change) and economic growth. TUSIAD (1996)
} 
By using public sector borrowing requirement (PSBR) as a proxy for credit -squeeze, we employed a simple econometric model in order to measure the correlation between the capacity utilization and the PSBR. In order to eliminate the effects of inflation over PSBR, we deflated PSBR with CPI index calculated as 1993=1TL. The strong correlation between capacity utilization and public sector borrowing requirement is displayed on figure 1. We calculate that $1000 \mathrm{TL}$ increase in PSBR (in real value) can lead to $1.26 \%$ reduction in capacity utilization of the manufacturing sector for the modeling period of 1996-2002.
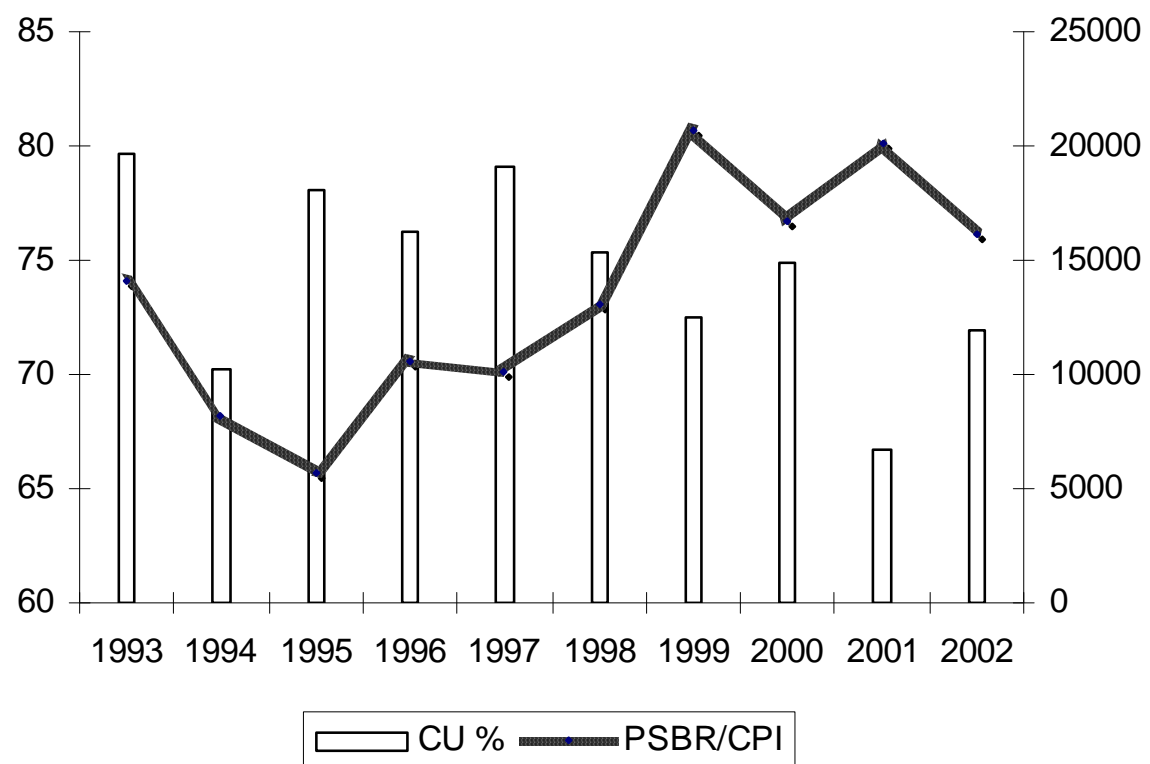

Figure 1. Government Deficits and Capacity Utilization

Source: Own calculation based on SPO electronic data delivery system: Retrieved on January 17,2004, http://www.dpt.gov.tr/ekutup

investigated the effects of government current and investment expenditure on Turkish economic growth in the 1960-1980 and 1980-1994 periods. They found that not only current expenditures, but also investment expenditures of government displayed significant negative correlation, especially after the 1980's. Moreover, both TUSIAD (1996), TUSAID (2001) and Tutar (2001) showed that the policy volatility and disarray in fiscal policy negatively correlated with the output for the last two decades. See Uyar (1996) for an overview over Turkish Public Finance in the last two decades. 


\section{Model Specification ${ }^{4}$}

The theoretical background for the static part of the model is based on the CGE modeling procedures developed by Dervis et al. (1982). We also use Bourguignon et al.(1991) and Forgeix et al. (1991) models in the dynamic part. In the dynamic part, the static solution for each period is linked through updating the stock variables, i.e. capital, labor and total factor productivity. Moreover, some of the parameters are updated over the time according to their historical trends.

The goods markets, factor markets, and the balance of payments are assumed to be brought into equilibrium through the Walrasian price adjustment mechanism. We set consumer price index as the numeraire, so that all the prices for commodities, for factors of production and exchange rate are determined relative to this index.

The model incorporates four productive sectors: agriculture, industry, private service, and government services. The model contains two primary factors: labor and capital. Labor and capital are assumed to be supplied by the households. Using nest structure, the firms in each sector, first, choose the optimal combination of intermediate input and value added and, second, choose optimum capital and labor (i.e. equation 9-11). In the second stage, the model also finds labor demand function. In the first stage, the intermediate input-value added combination is governed by constant elasticity of substitution (CES) function while the value added is governed by augmented Cobb-Douglass function. We assume that labor $\left(L D_{a t}\right)$ and capital $\left(K D_{a t}\right)$ and capacity utilization for capital determines the value added. The function obeys the usual properties, constant returns to scale, and a unitary elasticity of substitution between labor and capital. In the equation, $C U_{a, t}$ denotes the rate of capacity utilization in sector a, and $Z_{a t}$ is neutral technological progress or the shift parameter. ${ }^{5}$

\footnotetext{
${ }^{4}$ The list of equations can be found at the appendix, end of the article. Due to space limitation, we were unable to explain each equation in detail. Interested reader can see Robinson (1991) ,IFPRI (2001), Thissen (1999), Scarf (1973), Scarf et al. (1984), Taylor (1990), Shoven and Whalley (1984), Tunc (1997) and Aslan (2004), for survey on CGE models and the related theories in CGE modelling.

5 In Yeldan's (1997) model, the use of capacity utilization is due to mark-up price specification in that model. Although our model also implies mark-up due to use of Cobb-Douglas production function, our model does not incorporate quantity adjustment. Prices are still the main mechanism in the model to bring the system into the equilibrium. Moreover, since use of technology parameter in the creation of business cycle is criticized on the ground of absence of such large technological
} 
The trade relation with the rest of world (i.e. equation 15-18) is governed by standard CGE model practice where firms are assumed to market their commodities between domestic and world market with a constant elasticity of substitution (CET) function. Similarly, the sectoral import is assumed to follow Armington specification. ${ }^{6}$

The research distinguishes three types of households according to our SAM specification, namely low income, middle income, and high income households. The main sources of each household's income are labor income, distributed profits, government transfers, and remittance income from abroad and the relevant share parameters for each source are calibrated from the SAM. As it is very common in the other CGE models, we employed Keynesian type fixed share saving function for each households with different average propensity to save $\left(M P S_{h t}\right)$ where current savings depend $\left(\mathrm{SH}_{h t}\right)$ on current disposable income, and we calibrated the average propensity to save for each type of households from the SAM for Turkey.

Since the households make decisions about their savings first, the consumption for each household is equal to residual disposable income minus savings. The consumption demand for commodity $\mathrm{c}$ by the household $\mathrm{h}$ follows fixed expenditure share system which is calibrated from the $\mathrm{SAM}^{7}$. In the model, we also incorporate the housing investment by the households. ${ }^{8}$

shocks, we employ the shock to the capacity utilization as one of the source of large fluctuations in the output.

${ }^{6}$ Armington (1969) introduced the idea that the commodities traded in the world markets are homogonous while the commodities produced domestically might need not to be the same as the commodity imported from the rest of world. This specification proposes that sectoral imports and domestically produced goods are imperfect substitutes. In the Armington specification, a domestically produced commodity and an imported commodity are aggregated into a single "composite" good by using the CES function. The CES function can be considered as the utility function of the single agent which is confronted with the need to maximize the amount of composite commodity subject to his budget constraints

${ }^{7}$ Note that our use of fixed commodity share is based on the underlying assumption of the CobbDouglass type preference with a fixed share parameter.

${ }^{8}$ This may be the first CGE model that incorporating housing investment. In other CGE models, housing investment which accounted for around 40\% of total investment in Turkey in the 1990's is considered as fixed capital investment undertaken by the service sector. In the input-output data, housing is considered as a sector under the heading of service sector. Since the housing investment does not add to productive capacity of the Turkish economy, our treatment of independent housing investment would fit better the recent developments whereby large portions of savings were diverted to the housing market. Although we use an exogenous share parameter in housing investment determination, the large share of housing investment in total investment calls for further research. 
The government income $\left(Y G_{t}\right)$ is the sum of direct income tax from households, indirect tax revenue from domestic sales of goods and services, tariff revenues from imported commodities, corporate taxes, and net borrowings from abroad $(\overline{G F B O R})$, which is calculated as new borrowings from international markets and institutions minus interest and principal payments by the government to these markets and institutions.

The government overall income is determined by the model endogenously. In order to derive the overall government savings (deficit), we divide government expenditures into two major parts: i) non-interest expenditures $\left(G N I E_{t}\right)$; ii) interest payments $\left(\overline{G I N T P}_{t}\right)$. The government non-interest expenditures are set as a share of GNP and the share parameter is calculated according to the historical path for the base run. The non-interest expenditures are current expenditures, direct income transfer expenditures, and investment expenditures have been determined as the fixed share of GNIE $_{t}$ according to their historical pattern. ${ }^{9}$ Since the model does not include financial variables, we did not attempt to endogenize the government interest payments and set government interest payments according to its historical value [i.e. $\operatorname{GINTP}_{t}=\overline{\operatorname{GINTP}_{t}}$ ]. The overall government deficit $\left(G S A V_{t}\right)$ is equal to sum of primary deficit and interest payments.

The sectoral investment ( $D K_{a t}$ ) which is also known as investment by the sector of origin is determined according to the share parameter adjusted by the historical trend ( trend $_{a t}$ ). Since a unit of physical capital for each sector is a composite commodity of the goods and services, the investment by sector of destination is converted by using the capitalcomposition matrix $\left(k k_{a, c}\right)$ also known as B-Matrix. Each unit of capital goods is considered as a fixed-coefficent composite commodity whose price is determined by the weighted average of its components.

The model is assumed to be solved for every year which means that there exist positive prices that bring all the endogenous variables into

\footnotetext{
${ }^{9}$ Note that the share of current expenditures and transfer expenditures (excluding interest payments) did not show an up or down trend and they are relatively stable. On the other, hand, the government investment expenditures display significant fluctuations. Significant reduction in public investment is especially apparent during the years of crisis. Therefore, we take government investment expenditures as residual to capture this excess volatility.
} 
equilibrium. In the general equilibrium model, we need to normalize the prices system in the model so that although any individual price is allowed to vary according to preferences and technology determined by the system of equations, the overall prices are still kept constant at a fixed value. In order to normalize prices at some fixed value, the common approach is to establish a price index weighted average price of goods and services traded in the model, and set the value of this index to unity. ${ }^{10}$ We establish a consumer price index and assume that the system is normalized around the composite good prices. The weight for each good is calibrated according to consumer consumption expenditures for the base year.

The "system constraint" is the constraint that has to be satisfied by the economic system, but is not considered in the optimization decision of any micro agent (Robinson, 1989). Therefore, we need additional equations which are not subject to constraint optimization process by the micro-agent to bring the overall economy in a state where there is no excess supply or demand for goods and factor markets and the total savings are equal to investments. Since the model is an open economy model, the model also calls for an additional equation for the current account. The "closure rule," which is also related to the system constraint we described, comes from the fact that adding these constraints to the system requires some of the variables to be forced to be parameters in order to find a mathematical solution for the model. In other words, since the number of variables in the system becomes more than the number of the equations through adding the system constraint requirements, the only way to solve the model is to treat some of the variables to became exogenous. Therefore, the selection we described is a delicate elimination process which calls for empirical assistance.

In the goods markets, the main mechanism works through the relative price system, and, therefore, there is no "closure rule" required for this market to settle into a state of equilibrium. The composite good supply for commodity $\mathrm{c}$ is equal to the sum of consumer consumption demand, housing investment, government consumption, investment demand, intermediate input demand, and the stock changes.

${ }^{10}$ The other alternative is to set the exchange rate as unity so that domestic prices are moved around the exchange rate. In our model, it is one of the counterfactual experiments that require a flexible exchange rate. Therefore, we refrained from exploring this option. 
In the factor markets, there exist some structural elements that might be considered as deviations from the neoclassical rule. For example, adding unemployment into the system might be possible and, if this is the case, the nominal or real wages are set to fixed and the unemployment rate varies. In our model, we assume that there is no unemployment (or existing unemployment rate reflects natural rate of unemployment), and allow the wages and return from capital to clear the market. In particular, since our model incorporates the possibility that different sectors can pay different wages (or rate of return on capital), we assume that the real return difference variable and the average wage clear respectively the capital and labor markets. In other words, the model assumes that the capital demand in each sector is fixed, which implies that the overall return from capital is fixed while the real return difference can vary to bring the system into equilibrium.

In terms of the saving and investment equilibrium, we set average propensity to save by each households as fixed and government savings are taken as the difference between the government revenue and income, and the foreign savings are fixed. Since the behavior of the foreign savings also relates to the equilibrium in the current account balance, we assume that the exchange rate varies in order for the current account to be in equilibrium. ${ }^{11}$ The private investment is equal to the available savings in the economy. ${ }^{12}$

In the dynamic section, some of the parameters of the static model are updated according to the value of some of the variables solved in the static stage i.e., capital stock. In addition to this, some of the parameters are updated according to the trend observed from the data, i.e. government interest payments, terms of trade parameters or world price for imported goods and exported goods. Moreover, we assume that the total factor productivity follows the classical real business cycle specification:

\footnotetext{
${ }^{11}$ Foreign savings or capital inflows in the benchmark solution will be assigned the actual value taken from the balance of payments statistics. However, in the counterfactual experiments, we set foreign savings equal to zero. The experiment addresses the fact that the opponents of liberalization frequently mention the adverse effects of volatile capital account on the balance of payments. In Turkey, some argue that capital flows caused excessive volatility so that these flows, in particular short term capital flows, were in part restricted. Foreign savings should be considered as one of the policy parameters for the government. We will use the results of this experiment in the counterfactual analysis.

${ }^{12}$ The closure rule was discussed extensively in Taylor (1991), Dervis, De Melo and Robinson (1982), and Thissen (1999).
} 


$$
Z_{a t+1}=Z_{a, t}+t g_{t}+R A N_{a, t+1}
$$

We assume that the trend rate for total factor productivity is \%1 [i.e., $\left.\operatorname{tg}_{t}=0.01\right]$. In order to capture supply shock, i.e. earthquakes in Turkey, we adjust the random shock matrix $\left(R A N_{a, t+1}\right)$.

We set the labor supply growth rate according to the actual job creation rate for Turkish economy. The price of export and import is adjusted according to the Foreign Trade Price Index data set by SPO. During the period we cover, i.e. 1996-2000, world price index for Turkish exportable goods decline by $8.3 \%$ while the index shows a $7 \%$ decline in import prices which broadly suggest a $1.3 \%$ terms of trade shock. We adjust the world prices according to these indexes. After these adjustments, the arguments of shock matrix are very close to zero except for 1999 where there were two major earthquakes with a more than 30,000 death toll and economic losses were as much as $3 \%$ of GNP. The adverse effects of two major earthquakes in 1999 on the Turkish economy are introduced as a 5\% technology shock for each sector.

\section{Benchmark Results and Simulations}

In order to measure the relative success of the model, we solve it to see if it tracks the actual development of the Turkish economy in 19962001. Since the base run solution will serve as the benchmark for the counterfactual experiments, the accuracy of benchmark solution relative to actual economy would suggest the success of the model.

In order model to track the actual economy with precision, we follow the historical validation method described in Celasun (1986, p. 44). Firstly, for the base year of 1996, the model's algebraic equations and related parameters are calibrated according to the social accounting matrix of the base-year data set. Except capital stock, number of workers employed in sectors and elasticities, the share and shift parameters are calibrated exclusively from the SAM constructed by Aslan (2004) ${ }^{13}$. In the second stage, starting from the base year solution, we updated the some of the parameters of the model according to historically observed actual data for the time period the model covers, i.e. 1996-2000. In particular, among other things, we updated government non-interest

\footnotetext{
${ }^{13}$ The other data we use for this research is collected/calculated from various sources and will be explained in the appendix.
} 
expenditures, terms of trade, and the share of government expenditure in the government budget, government interest payments, etc. according to data from national accounting. In the third stage some of the technical parameters of the model are re-adjusted in an iterative manner until a convergence of the endogenous variables with their historical values is achieved. In particular, for example, we give 5\% negative technology shock to the economy for 1999 due to the earthquakes, and to reduce the employment in agriculture, observed in the actual economy, we increased the wage differential factor for the agricultural sector.

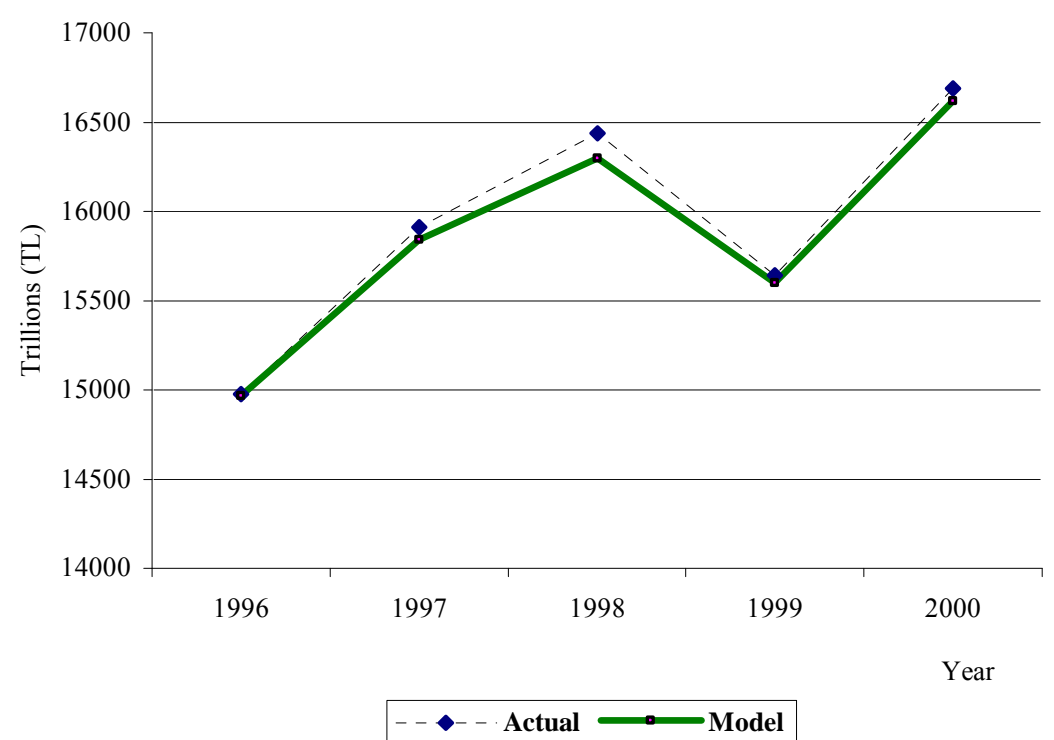

Figure 2. Model and Actual Real GNP

Source: Actual GNP from SPO , retrieved on January 17, 2004, http://www.dpt.gov.tr/ekutup

To validate the model's capacity in tracking the behavior of the Turkish economy over the period of 1996-2000, we use Figure 2 and Table 1. Figure 2 portrays the comparison between the actual data and model's result for real GNP ${ }^{14}$. Since the model is a real model (i.e. it does not include nominal variables), we deflated all the nominal numbers in the official statistics with the consumer price index where we set this

14 Due to space limitation, we did not display the comparisons of all important variables. However,Table-1 provide the comparisons of the important variables. 
index equal to 1 for 1996 and calculated a CPI index according to the actual CPI index calculated by the State Institute of Statistics.

The other items pertaining to the validation of the model in tracking the historical observed values are presented in Table 1. The model's GNP catches the actual historical GNP accurately. In the same periods the private investments are slightly lower than historical value due to the closure rule specified above.

Although there is some divergence from the historical data, we believe that the model results match the actual data relatively well and the results would qualify as a base solution for the counterfactual experiments.

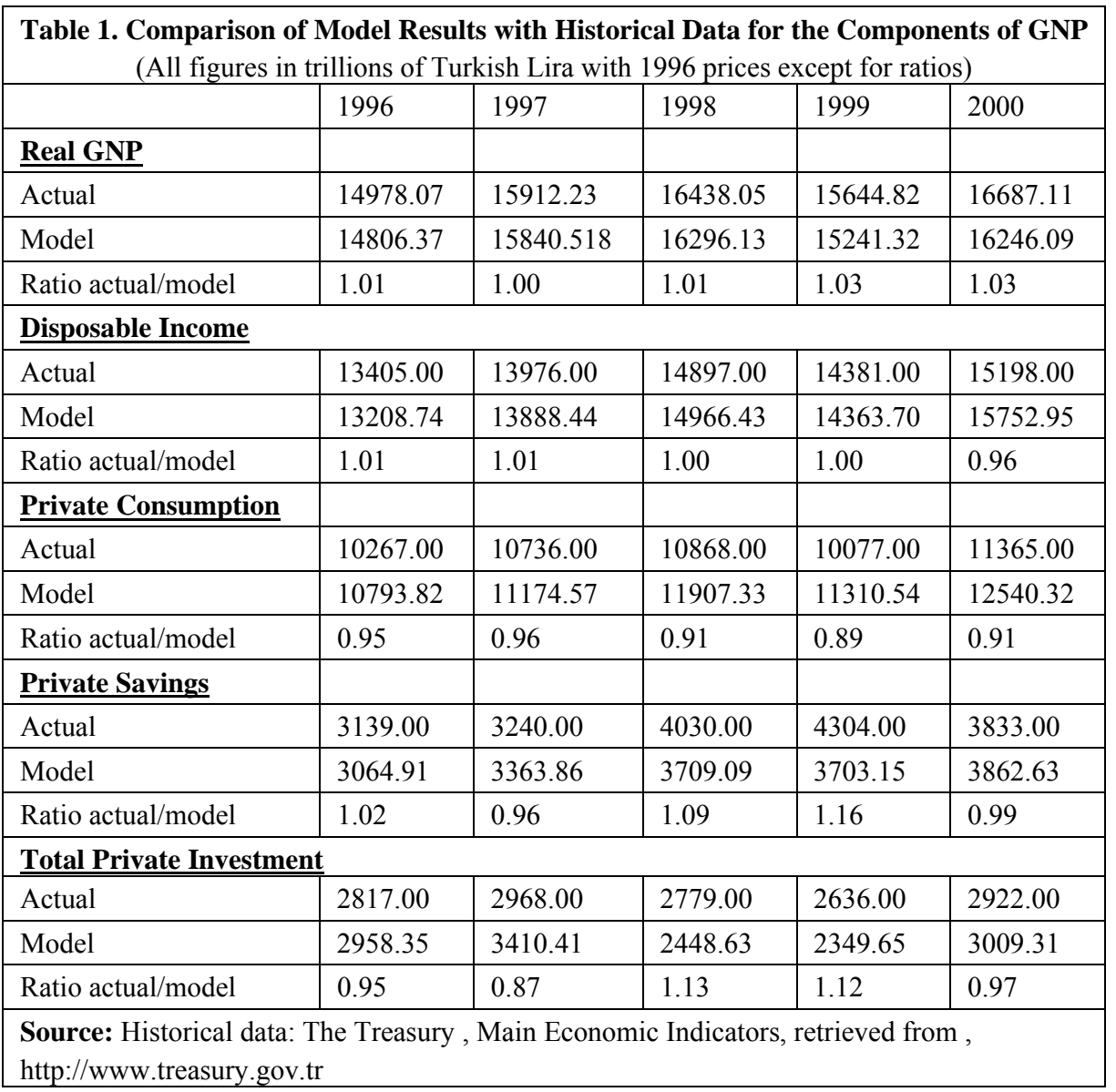

After passing the historical validation test, the model address the main question of: what would the economic path be if government followed 
fiscal austerity program during this period? In order to analyze the microeconomic and macroeconomic impacts of fiscal austerity policies with the alternative credibility assumptions, we will conduct two counterfactual experiments. The simulation experiments are based on the traditional fiscal austerity program suggested by the IMF for the developing countries. In the first experiment (EXP-A), we will reduce non-interest expenditures around $21 \%$ of GNP with the assumption that the historical interest payments would not change significantly. When the government policy is not credible, the default risk premium asked from government for its debt instruments would not change and, therefore, the reduction in the interest payments would not be significant. The reduction in interest payments is assumed to be equal to the additional primary surplus generated from the previous period.

In the second experiment (EXP-B) related to fiscal austerity, we will assume that the reduction in non-interest expenditures creates confidence among investors, and, as a result, the interest payments decline. The stabilization program is critically dependent on an improvement in expectations and a decline in interest rates. Alesine et al. (1990) for Italy, Bayoumi et al. (1995) for the US and Caselli, Giovannini and Lane (1999) for OECD countries, showed that when the government implements a fiscal austerity program associated with the generation of primary surplus, the interest rate on government debt instruments decline $^{15}$.

We will assume that the ratio of the government interest payments to the GNP will be same as the base year and would not increase, i.e. the base year interest payments to GNP ratio of $8.6 \%$ will remain intact for the 1998-2000 period. In addition to this, we assume that the second period interest rate would remain the same and a reduction in the interest payments will start at the third period, i.e. 1998.

In the first experiment, we reduce the government non-interest expenditures and adjust interest expenditures according to the primary surplus generated from the previous period. The maturity of government debt instruments in the last decade was around 240 days and, therefore,

${ }^{15}$ See Ozatay (1997) for the adverse effects of public debt in creation of financial crisis in 1994 for Turkey. OECD economic reports also underline the Turkish public-debt problem. See OECD (2001) for a good review. 
the additional primary surplus implicitly assumed to be paid for reducing the pressure from the government roll-over debt. The value of the parameters used in the counterfactual experiments is shown on Table 2 where EXP-A stands for fiscal austerity without credibility and EXP-B stands for fiscal austerity with credibility.

\begin{tabular}{|c|c|c|c|c|c|}
\hline \multicolumn{6}{|c|}{$\begin{array}{l}\text { Table 2. Parameters for Experiments EXP-A and EXB-B } \\
\text { (All figures in trillions of Turkish Lira with } 1996 \text { prices except for ratios) }\end{array}$} \\
\hline & Base Run & Base Run & -EXP A\&B- & -EXP A- & -EXP B- \\
\hline Year & GINTP $_{t}$ & $\mathrm{GNIE}_{\mathrm{t}} / \mathrm{GNP}_{\mathrm{t}}$ & $\mathrm{GNIE}_{\mathrm{t}} / \mathrm{GNP}_{\mathrm{t}}$ & GINTP $_{t}$ & GINTP $_{\mathrm{t}}$ \\
\hline 1996 & 1329 & 0.237 & 0.21 & 1329 & 1329 \\
\hline 1997 & 1088 & 0.228 & 0.21 & 836 & 836 \\
\hline 1998 & 1803 & 0.213 & 0.21 & 1517 & 1303 \\
\hline 1999 & 1942 & 0.280 & 0.21 & 1597 & 1219 \\
\hline 2000 & 2595 & 0.247 & 0.21 & 2137 & 1299 \\
\hline \multicolumn{6}{|c|}{$\begin{array}{l}\text { Note: } \text { GINTP }_{t}: \text { government interest payments, } \text { GNIE }_{t}: \text { non-interest expenditures, } \text { GNP }_{t} \\
\text { gross national product in } 1996 \text { prices. }\end{array}$} \\
\hline
\end{tabular}

\begin{tabular}{|l|l|l|l|l|l|}
\hline \multicolumn{7}{|c|}{ Table 3. The Experiment Results for EXP-A } \\
\hline & 1996 & 1997 & 1998 & 1999 & 2000 \\
\hline Real GNP & & & & & \\
\hline EXP-A & 14985.87 & 15971.69 & 16669.09 & 16653.01 & 17273.66 \\
\hline BASE & 14806.38 & 15840.52 & 16296.13 & 15241.32 & 16246.09 \\
\hline EXP/BASE & 1.01 & 1.01 & 1.02 & 1.09 & 1.06 \\
\hline Disposable Income & & & & & \\
\hline EXP-A & 13418.00 & 14095.04 & 15135.21 & 15198.02 & 16261.99 \\
\hline BASE & 13208.74 & 13888.45 & 14966.43 & 14363.70 & 15752.96 \\
\hline EXP/BASE & 1.02 & 1.01 & 1.01 & 1.06 & 1.03 \\
\hline Private Consumption & & & & & \\
\hline EXP-A & 10962.69 & 11339.43 & 12039.80 & 11957.76 & 12939.99 \\
\hline BASE & 10793.82 & 11174.58 & 11907.34 & 11310.55 & 12540.32 \\
\hline EXP/BASE & 1.02 & 1.01 & 1.01 & 1.06 & 1.03 \\
\hline Private Savings & & & & & \\
\hline EXP-A & 3105.30 & 3405.61 & 3745.41 & 3890.26 & 3971.99 \\
\hline BASE & 3064.92 & 3363.87 & 3709.10 & 3703.16 & 3862.64 \\
\hline EXP/BASE & 1.01 & 1.01 & 1.01 & 1.05 & 1.03 \\
\hline Total Private Investment & & & & & \\
\hline EXP-A & 3427.79 & 3750.37 & 3027.59 & 4031.92 & 4219.87 \\
\hline BASE & 2958.36 & 3410.42 & 2448.63 & 2349.66 & 3009.32 \\
\hline EXP/BASE & 1.16 & 1.10 & 1.24 & 1.72 & 1.40 \\
\hline
\end{tabular}


Table 4 . Experiment B Credible Fiscal Discipline

(All figures in trillions of Turkish Lira with 1996 prices except for ratios)

\begin{tabular}{|l|l|l|l|l|l|}
\hline & 1996 & 1997 & 1998 & 1999 & 2000 \\
\hline Real GNP & & & & & \\
\hline EXP-B & 14985.87 & 15971.69 & 16841.18 & 16987.95 & 17898.47 \\
\hline BASE & 14806.38 & 15840.52 & 16296.13 & 15241.32 & 16246.09 \\
\hline EXP/BASE & 1.01 & 1.01 & 1.03 & 1.11 & 1.10 \\
\hline Disposable Income & & & & & \\
\hline EXP-B & 13418.00 & 14095.04 & 15089.09 & 15144.93 & 16038.09 \\
\hline BASE & 13208.74 & 13888.45 & 14966.43 & 14363.70 & 15752.96 \\
\hline EXP/BASE & 1.02 & 1.01 & 1.01 & 1.05 & 1.02 \\
\hline Private Consumntion & & & & & \\
\hline EXP-B & 10962.69 & 11339.43 & 12002.54 & 11915.00 & 12759.85 \\
\hline BASE & 10793.82 & 11174.58 & 11907.34 & 11310.55 & 12540.32 \\
\hline EXP/BASE & 1.02 & 1.01 & 1.01 & 1.05 & 1.02 \\
\hline Private Savings & & & & & \\
\hline EXP-B & 3105.30 & 3405.61 & 3736.55 & 3879.93 & 3928.24 \\
\hline BASE & 3064.92 & 3363.87 & 3709.10 & 3703.16 & 3862.64 \\
\hline EXP/BASE & 1.01 & 1.01 & 1.01 & 1.05 & 1.02 \\
\hline TotalPrivate Investment & & & & & \\
\hline EXP-B & 3427.79 & 3750.37 & 3226.66 & 4390.99 & 4996.51 \\
\hline BASE & 2958.36 & 3410.42 & 2448.63 & 2349.66 & 3009.32 \\
\hline EXP/BASE & 1.16 & 1.10 & 1.32 & 1.87 & 1.66 \\
\hline
\end{tabular}

Table 5. Other Results for Experiment $A$ and $B$

(All figures in trillions of Turkish Lira with 1996 prices except for ratios)

\begin{tabular}{|l|l|l|l|l|l|}
\hline & 1996 & 1997 & 1998 & 1999 & 2000 \\
\hline EXPORT & & & & & \\
\hline BASE & 45019.28 & 49119.87 & 54891.92 & 45201.42 & 45642.45 \\
\hline EXP-A & 45899.72 & 49653.63 & 55625.62 & 49796.86 & 48360.56 \\
\hline IMPORT & 45899.72 & 49653.63 & 56235.42 & 50949.63 & 50526.99 \\
\hline BASE & & & & & \\
\hline EXP-A & 49965.39 & 51831.92 & 50964.12 & 50895.68 & 58090.86 \\
\hline EXP-B & 50845.83 & 52365.68 & 51697.82 & 55491.13 & 60808.97 \\
\hline GOVERNMENT DEFICIT & 50845.83 & 52365.68 & 52307.62 & 56643.90 & 62975.41 \\
\hline BASE & -1291.34 & -1254.88 & -1720.82 & -2486.38 & -2305.29 \\
\hline EXP-A & -859.89 & -954.75 & -1381.49 & -968.93 & -1199.92 \\
\hline EXP-B & -859.69 & -954.12 & -1172.00 & -599.05 & -382.25 \\
\hline WAGE EARNERS INCOME & & & & & \\
\hline BASE & 2071.48 & 2226.20 & 2335.69 & 2130.99 & 2292.79 \\
\hline EXP-A & 2120.05 & 2260.94 & 2377.76 & 2348.13 & 2425.35 \\
\hline EXP-B & 2120.05 & 2260.94 & 2403.58 & 2397.68 & 2518.40 \\
\hline
\end{tabular}


Table 3 contains the results of the experiment (EXP-A). The preliminary findings show that the increase in the private sector capital formation is remarkable. All the variables are higher than their base run values.

Table 4 presents the results of the second experiment. A comparison of the base run results for experiment I and experiment II for exports, imports and budget deficits are summed up in Table 5. The results indicate that the fiscal austerity policy affects wage earners positively. In particular, when the austere government policy cause the interest payments to decrease, the labor earning increase by $10 \%$ relative to the base run figures. The model shows that the stability of the government and fiscal discipline are beneficial for the society.

\section{Conslusion}

In regard to the possible effects of a fiscal austerity program with a varying degree of credibility, our CGE model shows that enforcing fiscal discipline ensures positive output effects, if the capacity utilization is assumed to be a function of the government deficit.

The structural school of thought frequently argues that capacity utilization is mainly determined by mark-up pricing. In such models, the mark-up pricing is assumed to follow countercyclical pattern. Consequently, they would predict that the fiscal austerity program employed in our counterfactual experiments would reduce the outputs. In this paper, we established a link between the capacity utilization and government deficit. The main argument was that when government's borrowing requirement increases, it pushes up the interest rate and squeezes the available credit in the market. When the available funds are squeezed, the private firms have difficulty to find necessary short term funds to finance their working capital needs for the advance payments of their intermediate input purchases as well as payments to other variable costs. Being unable to find the necessary funds, the firms engage in reducing their production and supply the products from their existing stocks. Therefore, our model argues that capacity utilization should be considered as the firms' response to the volatility in the financial markets caused by the excess government deficits. The basic transmission mechanism in the model is the credit squeeze system suggested by Naastaped (2002) in her financial CGE model. In this study, we showed 
that calibrated model with endogenous capacity utilization did excellent job in historical validation test. Therefore, the link between government deficit and its effects on the real sectors deserves further attention within the framework of a more sophisticated model which would include both the financial and stochastic features.

The model can be improved in various ways. Firstly, the inclusion of financial instruments with relevant risk factors will improve the link between budget deficit and interest rates and the link between interest rates and the way it is transmitted to working capital needs. Secondly, the model can be further improved if uncertainties are introduced into the model.

In the future, we will extend the basic model by constructing a financial SAM so that the model also includes financial variables. Moreover, we are planning to include a stochastic system. In particular, since firms make their intermediate input orders in advance, when the uncertainties are presents, higher interest rates or expensive foreign currency (due to large devaluations), firms would prefer to stay liquid and reduce its average costs. When there are two states of world i.e. good state and bad state, firms might choose to employ low capacity utilization if the expected state of world is bad and employ high capacity utilization if expected state of world is good. The stochastic elements, therefore, would be more appropriate in the explanation of the transmission mechanism.

\section{References}

Agenor., P.R., McDermott, C.J, \& Prasad, E.S. (2000). "Macroeconomic Fluctuations in Devloping Countries: Some Stylized Facts", The World Bank Review, Vol. 14. No.2 ,p. 251-285.

Alesina, A., Alessandro P.,, \& Tabellini G., (1990). Public Confidence and Debt Management: A Model and a Case Study for Italy. In R. Dornbusch and M. Draghi (ed.), Public Debt Management: Theory and History, Cambridge University Press, Cambridge.

Alesina, A. \& R. Perotti . (1995). "Fiscal Expansions and Adjustments in OECD Countries”, Economic Policy (21): 207-248. 
Aslan., M., (2004). Three Essays on Structural Economic Problems and Applied Model Construction for Turkey, Unpublished Ph.D. dissertation, George Mason University.

Bayoumi, T., Goldstein, M., \& Woglom, G. (1995). "Do Credit Markets Discipline Sovereign Borrowers? Evidence from U.S. States", Journal of Money, Credit, and Banking, Vol. 27 (November), pp. 1046-1059.

Bourguignon, F., de Melo, J. \& A. Suwa. (1991). "Modeling the Effects of Adjustment Programs on Income Distribution", World Development 19: 1527-1544, 1991.

Burnside,C., Eichenbaum, M., \& Rebelo, S.(1995). "Sectoral Solow Residuals”. NBER Working Papers, W5286, 1995.

Caselli, F., Giovannini , A., \& Lane, T. (1999). Fiscal Discipline and the Cost of Debt Service : Some Estimates for OECD Countries, unpublished manuscript.

Celasun, Merih. (1986). “A General Equilibrium Model of the Turkish Economy”, SIMLOG-1, METU Studies in Development, 13(1), pp. 2994.

Dervis, K., J. de Melo, \& S. Robinson., (1982). General Equilibrium Models for Development Policy. Cambridge: Cambridge University Press.

Erkumay, M.A., (2000). Kobi'lerin Sermaye Piyasasi Olanaklaridan Faydalanmasi. Sermaye Piyasasi Kurulu, Uzmanlik Tezi (in Turkish).

Fay,J. \& J Medoff (1985) "Labor and Output over the Business Cycle: Some direct evidence", American Economic Review 75, 638-655.

Forgeix, A. \& Sadoulet, E. (1994). "A Financial Computable General Equilibrium Models for the Analysis of Stabilization Programs", in J. Mercenier and T. Srinivisan (eds), Applied General Equilibrium and Economic Development : Present Achievement and Future Ttrends, Michigan University Press, Michigan, pp. 147-181. 
Grilli, V., Mascianddaro, D., \& Tabellini, G. (1991). "Political and Monetary Institutions and Public Financial Policies in the Industrial Democracies", Economic Policy, 13: pp. 341-392.

Istanbul Sanayi Odasi (1998). Turkiye'nin 500 Buyuk Sanayi Kurulusu: 1997. Istanbul Sanayi Odasi Dergisi, Ozel Sayi. Yil: 33, Sayi: 390.

Nastepad, C. (2000). The Public Sector Budget and Macroeconomic Performance; A real financial CGE analysis with portfolio choice with reference to India, Thesis Publishers, Amsterdam. Odekan, 9-28, New York Greenwood Press.

OECD. (2001).OECD Economic Surveys; 2000-2001, Turkey.

Ozatay, F. (1997). "The Lessons of the 1994 Crises in Turkey: Public Debt (Mis) Management and Confidence Crises", Yapi Kredi Economic Review 7:21-38.

Robinson, S. (1989). Multisectoral CGE Models, In the Handbook of Development Economics, Vol. II, edited by Hollis Chenery and T.N. Srinivasan. Amsterdam: North-Holland.

S. Robinson. (1991). "Macroeconomics, financial variables, and Computable General Equilibrium models", World Development, 19(11):1509-1525.

Sariaslan., H. (1994). Kucuk ve Orta Olcekli Isletmelerin Finansal Sorunlari: Cozum Icin bir Paket Onerisi, Ankara. TOBB.

Scarf, H. E. (1973). The Computation of Economic Equilibrium Models, Yale University Press, New Haven and London.

Scarf, H.E. \& Shoven, J.B. (1984). Applied General Equilibrium Analysis, Cambridge University Press, Cambriedge.

Shoven, J.B., \& Whalley, J.(1984). “Applied General Equilibrium Models of Taxation and International Trade : An introduction and Survey”, Journal of Economic Literature, Vol. 22(3) ,pp. 1007-1051.

Taylor, L. (1990). Socially Relevant Policy Analysis: Structural Computable General Equilibrium Models for Developing World, Cambridge (MA), MIT Press. 
Taylor, L.(1991). Short Run Model Closure and Steady State Growth, Income Distribution, Inflation, and Growth; Lectures on Structuralist Macroeconomic Theory, MIT Press, London.

Thissen, M., (1999). Financial CGE models Two Decades of Research in Financial CGE Models, Research Papers, SOM, University of Groningen, 99c 26.

Tunc, G. I.(1997). A financial computable general equilibrium model for Turkey: Policy Analysis with 1990 data, An unpublished $\mathrm{PhD}$ thesis.

TUSIAD. (2001), Turkiye Ekonomisi 2001 Yili Raporu, Yayin No. TUSIAD-T/2001-12-316.

TUSIAD. (1996). Turkiyede Kamu Sektoru Sorunlari No, TUSIAD-T /1996-36

Tutar I., \& Tansel., A. (2001). Political Business Cycle, and Power Dispersion in Turkey: Can the Coalitions Be Successful?, Unpublished Ph.D. dissertation, METU.

Uyar B.(1996). Economy and Public Finances in Turkey in the 1980s, in The Fiscal System and Economic Development, eds., Sohrab Abizzadeh and Mahmood Yousefi, Nova Science Publishing.

Yeldan , E.,(1997). Financial Liberalization and Fiscal Repression in Turkey: Policy Analaysis in a CGE Model with Financial Markets, Journal of Policy Modeling 19:79-117.

Yörük., M. (2002). Son Ekonomik Krizin KOBI’ler Uzerindeki Etkisi ve Tokat Ili Ornegi. unpublished manuscript.

Appendix

I) List of Equations:

\begin{tabular}{|l|l|l|}
\hline Indexes & & \\
\hline $\boldsymbol{t}$ & Time /year & $1996-2001$ \\
\hline $\boldsymbol{a}$ & Sector/activity & Agriculture, Industry, Service and Government \\
\hline $\boldsymbol{c}$ & Commodity & Agriculture, Industry, Service and Government \\
\hline $\boldsymbol{h}$ & Households & Poor, Medium Income and Rich \\
\hline & & \\
\hline
\end{tabular}




\begin{tabular}{|l|l|l|}
\hline A Price Block & Domestic price of \\
exports & $\mathbf{1}$ \\
\hline$P E_{c t}=p w e_{c t} \cdot E X R_{t}$ & $\begin{array}{l}\text { Price of import in } \\
\text { TL }\end{array}$ & $\mathbf{2}$ \\
\hline$P M_{c t}=p w m_{c t} \cdot\left(1+t a r_{c t}\right) \cdot E X R_{t}$ & Revenue price & $\mathbf{3}$ \\
\hline$P X_{c t}=\left(\frac{P D_{c t} \cdot Q D_{c t}+P E_{c t} \cdot Q E_{c t}}{Q X_{c t}}\right)$ & $\begin{array}{l}\text { Composite good } \\
\text { price }\end{array}$ & $\mathbf{4}$ \\
\hline$P Q_{c t}=\left(\frac{P D_{c t} \cdot Q D_{c t}+P M_{c t} \cdot Q M_{c t}}{Q Q_{c t}}\right) \cdot\left(1+s t a x_{c t}\right)$ & $\begin{array}{l}\text { Intermediate input } \\
\text { price }\end{array}$ & $\mathbf{5}$ \\
\hline$P N_{a t}=\sum_{c} i o_{c a} \cdot P Q_{c t}$ & $\begin{array}{l}\text { Price of value } \\
\text { added }\end{array}$ & $\mathbf{6}$ \\
\hline$P V A_{a t} \cdot Q V A_{a t}=P A_{a t} \cdot Q A_{a t}-P N_{a t} \cdot Q N_{a t}$ & $\begin{array}{l}\text { Price of capital for } \\
\text { sector a }\end{array}$ & $\mathbf{7}$ \\
\hline$P K_{a t}=\sum_{c} k k_{a c} \cdot P Q_{c t}$ & $\begin{array}{l}\text { Consumer price } \\
\text { index }\end{array}$ & $\mathbf{8}$ \\
\hline$C P I_{t}=\sum_{c} c w t s_{c} \cdot P Q_{c t}$ & & \\
\hline
\end{tabular}

\begin{tabular}{|c|c|c|c|}
\hline \multicolumn{2}{|c|}{ Variables and Parameters } & \multirow[b]{2}{*}{$P D_{c}$} & \multirow[b]{2}{*}{$\begin{array}{l}\text { domestic price received by } \\
\text { sector c }\end{array}$} \\
\hline$P V A_{a}$ & price of value added & & \\
\hline$P A_{a}$ & activity price & $P E_{c}$ & $\begin{array}{l}\text { price of export in domestic } \\
\text { currency received by } \\
\text { domestic sector }\end{array}$ \\
\hline$P Q_{c}$ & composite price & $P M_{C}$ & $\begin{array}{l}\text { price of import in domestic } \\
\text { currency for commodity c }\end{array}$ \\
\hline$P X_{c}$ & $\begin{array}{l}\text { average price received by } \\
\text { sector a }\end{array}$ & $Q M_{c}$ & imports \\
\hline$E X R$ & exchange rate $; 1 \$$ us $=\mathrm{tl}$ & $Q X_{c}$ & $\begin{array}{l}\text { total domestic production } \\
\text { for good c }\end{array}$ \\
\hline$Q D_{c}$ & domestic sales quantity & $Q Q_{C}$ & total domestic absorption \\
\hline$Q E_{c}$ & exports & $p w e_{c}$ & price of exports \\
\hline $\operatorname{stax}_{c}$ & sales tax rate & $\operatorname{tar}_{c}$ & $\begin{array}{l}\text { tariff rate for imported com. } \\
\text { C }\end{array}$ \\
\hline$p w m_{c}$ & price of imports in US\$ & $\mathrm{Cwts}_{\mathrm{C}}$ & $\begin{array}{l}\text { weight for consumer price } \\
\text { index }\end{array}$ \\
\hline
\end{tabular}




\begin{tabular}{|c|c|c|}
\hline B-) Production, Trade and Employment Block & & \\
\hline$Q A_{a t}=u x_{a t} \cdot\left[\eta_{a t} \cdot Q V A_{a t}^{-\rho_{a}^{x}}+\left(1-\eta_{a t}\right) \cdot Q N_{a t}^{-\rho_{a}^{x}}\right]^{-1 / \rho_{a}^{x}}$ & $\begin{array}{l}\text { First level in } \\
\text { production; value } \\
\text { added and } \\
\text { intermediate input } \\
\text { employment }\end{array}$ & 9 \\
\hline$Q V A_{a t}=Q N_{a t}\left(\frac{P N_{a t}}{P V A_{a t}} \frac{\eta_{a t}}{\left(1-\eta_{a t}\right)}\right)^{1 / 1+\rho_{a}^{x}}$ & $\begin{array}{l}\text { First order } \\
\text { condition for } \\
\text { equation 9: } \\
\text { optimum } \\
\text { intermediate input } \\
\text { value added } \\
\text { combination }\end{array}$ & 10 \\
\hline$Q V A_{a t}=Z_{a t} L D_{a t}^{\alpha_{a}}\left(C U_{a, t} \overline{K D}_{a t}\right)^{1-\alpha_{a t}}$ & $\begin{array}{l}\text { The second level } \\
\text { production; } \\
\text { primary input } \\
\text { employment }\end{array}$ & 11 \\
\hline$L D_{a t}=\frac{\alpha_{a} \cdot P V A_{a t} \cdot Q V A_{a t}}{W_{t} \cdot W D I S T_{a t}}$ & Labor demand & 12 \\
\hline$R_{t} \cdot R D I S T_{a t}=\frac{\left(1-\alpha_{a}\right) \cdot P V A_{a t} \cdot Q V A_{a t}}{\overline{K D}_{a t}}$ & Capital demand & 13 \\
\hline$Q I N T_{c a t}=i o_{c a t} \cdot Q N_{a t}$ & $\begin{array}{l}\text { Intermediate input } \\
\text { demand: } \\
\text { commodity c } \\
\text { demand by sector a }\end{array}$ & 14 \\
\hline$Q X_{c t}=a t_{c t}\left[\delta_{c}^{c e t} \cdot Q D_{c t}^{\rho_{c}^{c e t}}+\left(1-\delta_{c}^{c e t}\right) \cdot Q E_{c t}^{\rho_{c}^{c e t}}\right]^{-1 / \rho_{c}^{c c t}}$ & $\begin{array}{l}\text { Supply function or } \\
\text { CET (constant } \\
\text { elasticity of } \\
\text { transformation) } \\
\end{array}$ & 15 \\
\hline$\frac{Q D_{c t}}{Q E_{c t}}=\left[\frac{\left(1-\delta_{c}^{c e t}\right)}{\delta_{c}^{c e t}} \cdot \frac{P E_{c t}}{P D_{c t}}\right]^{-\sigma_{c}^{c e t}}, \sigma_{c}^{c e t}=\frac{1}{\rho_{c}^{c e t}-1}$ & $\begin{array}{l}\text { Optimum output } \\
\text { distribution: } \\
\text { optimize eq.14 } \\
\text { subject to domestic } \\
\text { and export prices }\end{array}$ & 16 \\
\hline$Q Q_{c t}=a q_{c t} \cdot\left[\delta_{c}^{q} \cdot Q M_{c t}^{-\rho_{c}^{q}}+\left(1-\delta_{c}^{q}\right) \cdot Q D_{c t}^{-\rho_{c}^{q}}\right]^{-1 / \rho_{c}^{q}}$ & $\begin{array}{l}\text { Armington } \\
\text { specification }\end{array}$ & 17 \\
\hline$\frac{Q M_{c t}}{Q D_{c t}}=\left[\frac{\delta_{c}^{q}}{\left(1-\delta_{c}^{q}\right)} \cdot \frac{P D_{c t}}{P M_{c t}}\right]^{1 / 1+\rho_{c}^{q}}$ & $\begin{array}{l}\text { Optimum domestic } \\
\text { import } \\
\text { combination: } \\
\text { optimize eq. } 17 \\
\text { subject to domestic } \\
\text { and import prices }\end{array}$ & 18 \\
\hline
\end{tabular}


$C U_{a t}=\beta 0+w_{g h t}{ }_{t a} S A V_{t} / C P I_{t}$

Capacity

19 utilization

specification

\begin{tabular}{|c|c|c|c|}
\hline \multicolumn{2}{|c|}{ Variables and Parameters } & \multirow[b]{2}{*}{$\mathrm{QINT}_{c a}$} & \multirow[b]{2}{*}{$\begin{array}{l}\text { intermediate input } \\
\text { demand }\end{array}$} \\
\hline$Q_{a t}$ & total output & & \\
\hline$Q V A_{a t}$ & value added & $L D_{a t}$ & labor demand \\
\hline$Q N_{a t}$ & $\begin{array}{l}\text { level of intermediate } \\
\text { input in sector a }\end{array}$ & $K D_{a t}$ & demand for capital \\
\hline$C U_{a t}$ & capacity utilization & $W_{t}$ & nominal wages \\
\hline$Q D_{c}$ & domestic sales & $W_{D I S T}$ & $\begin{array}{l}\text { wage differential } \\
\text { factor }\end{array}$ \\
\hline$Q E_{c}$ & exports & $R D I S T_{a t}$ & $\begin{array}{l}\text { return difference for } \\
\text { sectors }\end{array}$ \\
\hline$R_{t}$ & $\begin{array}{l}\text { average return from } \\
\text { capital }\end{array}$ & $\sigma_{a}=1 / 1+\rho_{a t}$ & $\begin{array}{l}\text { elasticity of } \\
\text { substitution between } \\
\text { intermediate input } \\
\text { and value added }\end{array}$ \\
\hline$u x_{a t}$ & $\begin{array}{l}\text { shift parameter for } \\
\text { the first level } \\
\text { production function }\end{array}$ & io $c a$ & $\begin{array}{l}\text { input-output } \\
\text { coefficient }\end{array}$ \\
\hline$\eta_{a t}$ & $\begin{array}{l}\text { share parameter for } \\
\text { the first level } \\
\text { production function }\end{array}$ & $Z_{a t}$ & $\begin{array}{l}\text { Cobb-Douglas tech. } \\
\text { parameter }\end{array}$ \\
\hline$\rho_{a t}$ & $\begin{array}{l}\text { exponent for the first } \\
\text { level production } \\
\text { function }\end{array}$ & $\alpha_{a}$ & $\begin{array}{l}\text { Cobb Douglas share } \\
\text { parameter. }\end{array}$ \\
\hline$\rho_{c t}^{c e t}$ & $\begin{array}{l}\text { CET function } \\
\text { exponent }\end{array}$ & $a t_{a t}$ & $\begin{array}{l}\text { shift parameter for } \\
\text { CET }\end{array}$ \\
\hline$\sigma_{c t}^{c e t}=1 / 1+\rho_{c t}^{c e t}$ & $\begin{array}{l}\text { elasticity of } \\
\text { substitution in CET: } \\
\text { elasticity of } \\
\text { substation between } \\
\text { supplying domestic } \\
\text { market versus world } \\
\text { market }\end{array}$ & $\delta_{c}^{c e t}$ & $\begin{array}{l}\text { share parameter for } \\
\text { CET }\end{array}$ \\
\hline$a q_{a t}$ & $\begin{array}{l}\text { shift parameter for } \\
\text { Armington function }\end{array}$ & $\sigma_{c t}^{q}=1 / 1+\rho_{c t}^{q}$ & $\begin{array}{l}\text { elasticity of } \\
\text { substitution in } \\
\text { Armington: }\end{array}$ \\
\hline$\delta_{c}^{q}$ & $\begin{array}{l}\text { share parameter for } \\
\text { Armington function }\end{array}$ & $w_{g h t}$ & $\begin{array}{l}\text { elasticity of capacity } \\
\text { utilization wrt } \\
\text { government deficit to } \\
\text { gnp ratio }\end{array}$ \\
\hline
\end{tabular}




\begin{tabular}{|l|l|l|l|}
\hline$\rho_{c t}^{q}$ & $\begin{array}{l}\text { Armington function } \\
\text { exponent }\end{array}$ & & \\
\hline
\end{tabular}

\begin{tabular}{|c|c|c|}
\hline C-Institutions & & \\
\hline$\overline{Y L A B_{t}}=\sum_{a} W_{a_{t}} \cdot W D I S T_{a t} \cdot L D_{a, t}+W G_{t} \cdot \overline{G L A B_{t}}$ & $\begin{array}{l}\text { Labor } \\
\text { income }\end{array}$ & 20 \\
\hline$K I N C_{a t}=R_{a t} R D I S T_{a t} \cdot \overline{K D_{t}}$ & $\begin{array}{l}\text { Capital } \\
\text { income }\end{array}$ & 21 \\
\hline$K N E T=(1-k t a x) \cdot\left(\sum_{a} K I N C_{a}+\overline{G I N T P}_{t}\right)$ & $\begin{array}{l}\text { After tax } \\
\text { income }\end{array}$ & 22 \\
\hline$D A G I T_{t}=\left(1-r e t_{t}\right)\left(K N E T_{t}-\sum_{c} P Q_{c} \cdot d s t_{c, t}\right)$ & $\begin{array}{l}\text { Distributed } \\
\text { profit }\end{array}$ & 23 \\
\hline $\begin{array}{l}Y H_{h t}=\mu l a b_{h} \cdot Y L A B_{t}+\mu r e m_{h}\left(E R_{t} \cdot \overline{\operatorname{REMIT}_{t}}\right) \\
+\mu g y_{h} \cdot \overline{G Y T R N_{t}}+\mu \operatorname{Gap}_{h} \cdot \mathrm{DAGIT}_{t}\end{array}$ & $\begin{array}{l}\text { Household } \\
\text { income }\end{array}$ & 24 \\
\hline$Y D H_{h t}=\left(1-t y_{h t}\right) \cdot Y H_{h t}$ & $\begin{array}{l}\text { Household } \\
\text { disposable } \\
\text { income }\end{array}$ & 25 \\
\hline $\begin{array}{l}\mathrm{YG}_{\mathrm{t}}=\left(\sum_{\mathrm{c}} \mathrm{tq}_{\mathrm{ct}} \cdot \mathrm{PQ}_{\mathrm{ct}} \cdot \mathrm{QD}_{\mathrm{ct}}\right)+ \\
\left(\mathrm{EXR}_{\mathrm{t}} \cdot \sum_{\mathrm{c}} \mathrm{tm}_{\mathrm{ct}} \cdot \mathrm{pwm}_{\mathrm{ct}} \cdot \mathrm{QM}_{\mathrm{ct}}\right)+ \\
\left(\sum_{\mathrm{h}} \mathrm{ty}_{\mathrm{ht}} \cdot \mathrm{YH}_{\mathrm{ht}}\right)+\mathrm{ktax}_{\mathrm{t}} \cdot\left(\sum_{\mathrm{a}} \mathrm{KINC}_{\mathrm{a}}+\overline{\mathrm{GINTP}}_{\mathrm{t}}\right)+ \\
\mathrm{EXR}_{\mathrm{t}} \overline{\left(\mathrm{GFBOR}_{\mathrm{t}}\right)}\end{array}$ & $\begin{array}{l}\text { Income for } \\
\text { government }\end{array}$ & 26 \\
\hline$S T O K_{t}=\sum_{c} P Q_{c t} d s t_{c t}$ & $\begin{array}{l}\text { Stock } \\
\text { changes }\end{array}$ & 27 \\
\hline$D K_{a t}=$ trend $_{a t} \cdot \frac{O Y A T_{t}}{P K_{a t}}$ & $\begin{array}{l}\text { Investment } \\
\text { by sector of } \\
\text { destination: } \\
\text { capital stock } \\
\text { increase for } \\
\text { sector a }\end{array}$ & 28 \\
\hline$Q I N V_{c t}=\sum_{a} k k_{a, c} \cdot D K_{a t}$ & $\begin{array}{l}\text { Investment } \\
\text { by sector of }\end{array}$ & 29 \\
\hline
\end{tabular}




\begin{tabular}{|c|c|c|}
\hline & origin & \\
\hline$S H_{h t}=M P S_{h, t} \cdot Y D H_{h t}$ & $\begin{array}{l}\text { Household } \\
\text { savings }\end{array}$ & 30 \\
\hline$H E V_{h t}=\mu e v_{h t} \cdot S H_{h t}$ & $\begin{array}{l}\text { Household } \\
\text { housing } \\
\text { investment }\end{array}$ & 31 \\
\hline $\mathrm{TKONUT}_{t}=\sum_{h} H E V_{h t}$ & $\begin{array}{l}\text { Total } \\
\text { housing } \\
\text { investment }\end{array}$ & 32 \\
\hline$H I N V_{c t}=\frac{h q_{c} \cdot T K O N U T_{t}}{P Q_{c t}}$ & $\begin{array}{l}\text { Demand of } \\
\text { good c used } \\
\text { in housing } \\
\text { investment }\end{array}$ & 33 \\
\hline$Q H_{c, h t}=\frac{\beta_{c, h} \cdot\left(Y D H_{h t}-S H_{h t}\right)}{P Q_{c t}}$ & $\begin{array}{l}\text { Household } \\
\text { consumption } \\
\text { demand for } \\
\text { good c }\end{array}$ & 34 \\
\hline$G N I E_{t}=\operatorname{gtar}_{t} \cdot G D P_{t}$ & $\begin{array}{l}\text { Non interest } \\
\text { payments } \\
\text { target }\end{array}$ & 35 \\
\hline$G E N_{t}=G N I E_{t}-\overline{G I N T P}_{t}$ & $\begin{array}{l}\text { Total } \\
\text { government } \\
\text { spending }\end{array}$ & 36 \\
\hline$G P D E F_{t}=Y G-G N I E_{t}$ & $\begin{array}{l}\text { Government } \\
\text { primary } \\
\text { deficit }\end{array}$ & 37 \\
\hline$G S A V_{t}=G P D E F+\overline{G I N T P}_{t}$ & $\begin{array}{l}\text { Government } \\
\text { deficit }\end{array}$ & 38 \\
\hline$G C_{t}=g c h_{t} G N I E_{t}$ & $\begin{array}{l}\text { Government } \\
\text { consumption }\end{array}$ & 39 \\
\hline$G W B L_{t}=g m s_{t} G N I E_{t}$ & $\begin{array}{l}\text { Government } \\
\text { wage bill }\end{array}$ & 40 \\
\hline$G Y R N=g_{s s k_{t} \cdot G N I E_{t}}$ & $\begin{array}{l}\text { Government } \\
\text { income } \\
\text { transfers }\end{array}$ & 41 \\
\hline$G I N V_{t}=\left(1-g c h_{t}-g s s k_{t}-g m s_{t}\right) \cdot G N I E_{t}$ & Government & 42 \\
\hline
\end{tabular}




\begin{tabular}{|l|l|l|}
\hline & investments & \\
\hline$G D C_{c t}=g_{c o n} \frac{G C_{t}}{P Q_{c t}}$ & $\begin{array}{l}\text { Demand for } \\
\text { good c by } \\
\text { government } \\
\text { as current } \\
\text { expenditure }\end{array}$ & $\mathbf{4 3}$ \\
\hline$G D I_{c t}=$ gyat $_{c t} \frac{G I N V_{t}}{P Q_{c t}}$ & $\begin{array}{l}\text { Demand for } \\
\text { good c by } \\
\text { government } \\
\text { as } \\
\text { investment }\end{array}$ & $\mathbf{4 4}$ \\
\hline$G W B L_{t}=W G_{t} \cdot \overline{G L A B}_{t}$ & $\begin{array}{l}\text { Wages for } \\
\text { civil } \\
\text { servants }\end{array}$ & $\mathbf{4 5}$ \\
\hline
\end{tabular}

\begin{tabular}{|c|c|c|c|}
\hline \multicolumn{2}{|c|}{ Variables and Parameters } & \multirow[b]{2}{*}{$Q H_{c t}$} & \multirow[b]{2}{*}{$\begin{array}{l}\text { demand for good c as } \\
\text { consumption }\end{array}$} \\
\hline$Y L A B_{t}$ & labor income & & \\
\hline$K I N C_{a t}$ & $\begin{array}{l}\text { capital income for } \\
\text { sector a }\end{array}$ & GNIE $_{t}$ & $\begin{array}{l}\text { government non } \\
\text { interest expenditures }\end{array}$ \\
\hline$K N E T_{t}$ & after tax income & $G D P_{t}$ & gross domestic product \\
\hline$D_{A G I T}$ & distributed income & $G E N_{t}$ & $\begin{array}{l}\text { total government } \\
\text { expenditures }\end{array}$ \\
\hline$Y H_{h t}$ & $\begin{array}{l}\text { household gross } \\
\text { income }\end{array}$ & $G P D E F_{t}$ & $\begin{array}{l}\text { government primary } \\
\text { deficit }\end{array}$ \\
\hline$Y D_{h t}$ & $\begin{array}{l}\text { household disposable } \\
\text { income }\end{array}$ & $G S A V_{t}$ & government deficit \\
\hline$Y G_{t}$ & government revenue & $G C_{t}$ & $\begin{array}{l}\text { government current } \\
\text { expenditures }\end{array}$ \\
\hline $\mathrm{STOK}_{t}$ & stock changes & $G W B L_{t}$ & government wage bill \\
\hline$D K_{a t}$ & investment by sector a & $G Y T R N_{t}$ & $\begin{array}{l}\text { government direct } \\
\text { transfer expenditures }\end{array}$ \\
\hline $\mathrm{QINV}_{c t}$ & $\begin{array}{l}\text { demand for good c as } \\
\text { investment demand }\end{array}$ & $G I N V_{t}$ & $\begin{array}{l}\text { government investment } \\
\text { expenditures }\end{array}$ \\
\hline$S H_{h t}$ & household savings & $G D C_{c t}$ & $\begin{array}{l}\text { demand for good c as } \\
\text { current expenditures }\end{array}$ \\
\hline$H E V_{h t}$ & $\begin{array}{l}\text { household housing } \\
\text { investment }\end{array}$ & $G D I_{c t}$ & $\begin{array}{l}\text { demand for good } \mathrm{c} \text { as } \\
\text { investment } \\
\text { expenditures }\end{array}$ \\
\hline $\mathrm{TKONUT}_{t}$ & $\begin{array}{l}\text { total household } \\
\text { investment }\end{array}$ & $W G_{t}$ & $\begin{array}{l}\text { wage rate for civil } \\
\text { servants }\end{array}$ \\
\hline
\end{tabular}




\begin{tabular}{|c|c|c|c|}
\hline$H I N V_{c t}$ & $\begin{array}{l}\text { good c demand as } \\
\text { housing investment }\end{array}$ & $d s t_{c t}$ & $\begin{array}{l}\text { stock changes for good } \\
\text { c }\end{array}$ \\
\hline $\operatorname{ktax}_{t}$ & $\begin{array}{l}\text { capital tax including } \\
\text { government factor } \\
\text { income }\end{array}$ & trend $_{a t}$ & $\begin{array}{l}\text { trend for investment by } \\
\text { sector a }\end{array}$ \\
\hline ret $_{t}$ & retained earning rate & $k k_{c a}$ & $\begin{array}{l}\text { capital composition } \\
\text { matrix }\end{array}$ \\
\hline$\mu l a b_{h}$ & $\begin{array}{l}\text { share for household for } \\
\text { labor income }\end{array}$ & $h q_{c t}$ & $\begin{array}{l}\text { unit of good c need per } \\
\text { unit of housing }\end{array}$ \\
\hline urem $_{h}$ & $\begin{array}{l}\text { share for household for } \\
\text { remittance }\end{array}$ & $\mu e v_{h}$ & $\begin{array}{l}\text { share of savings } \\
\text { devoted to housing } \\
\text { investment }\end{array}$ \\
\hline$\mu g y_{h}$ & $\begin{array}{l}\text { share for household for } \\
\text { government direct } \\
\text { transfer }\end{array}$ & $\beta_{c h}$ & $\begin{array}{l}\text { share of good c in } \\
\text { housing total } \\
\text { consumption spending }\end{array}$ \\
\hline$\mu \operatorname{cap}_{h}$ & $\begin{array}{l}\text { share for household for } \\
\text { dividend payments }\end{array}$ & $g c h_{t}$ & $\begin{array}{l}\text { share parameter for } \\
\text { current expenditures in } \\
\text { gnie }\end{array}$ \\
\hline$t y_{h t}$ & direct income tax rate & $g m s_{t}$ & $\begin{array}{l}\text { wage payment share in } \\
\text { gnie }\end{array}$ \\
\hline$\overline{R E M I T}_{t}$ & remittance income & $g_{s s k_{t}}$ & $\begin{array}{l}\text { transfer payments share } \\
\text { in gnie }\end{array}$ \\
\hline$\overline{G F B O R}_{t}$ & $\begin{array}{l}\text { government foreign } \\
\text { borrowing (net) }\end{array}$ & $\operatorname{gcon}_{c t}$ & $\begin{array}{l}\text { share of good } \mathrm{c} \text { in } \\
\text { current expenditures }\end{array}$ \\
\hline gyat $_{c t}$ & $\begin{array}{l}\text { share of good c in } \\
\text { investment } \\
\text { expenditures }\end{array}$ & $\overline{G L A B}_{t}$ & civil servants total \\
\hline
\end{tabular}

\begin{tabular}{|l|l|l|}
\hline D- Closure,Aggregates and Dynamics & & \\
\hline$G D P_{t}=\sum_{a} P V A_{a, t} \cdot Q A_{a, t}+W G_{t} \cdot \overline{G L A B}_{t}$ & GDP & $\mathbf{4 6}$ \\
$+\left(E X R_{t} \cdot \sum_{c} t m_{c t} \cdot p w m_{c t} \cdot Q M_{c t}\right)$ & & \\
\hline$K S=\sum_{a} K D_{a, t}$ & $\begin{array}{l}\text { Equilibrium in } \\
\text { capital }\end{array}$ & $\mathbf{4 7}$ \\
\hline$L S_{t}=\sum_{a} L D_{, a t}$ & $\begin{array}{l}\text { Equilibrium in } \\
\text { labor market }\end{array}$ & $\mathbf{4 8}$ \\
\hline$\sum_{h}\left(S H_{h t} \cdot-H E V_{h t}\right)+E X R_{t} \cdot F S A V_{t}+G S A V_{t}$ & $\begin{array}{l}\text { Saving investment } \\
\text { closure }\end{array}$ & $\mathbf{4 9}$ \\
$=\left(O Y A T_{t}-r e t_{t} . D A G I T_{t}\right)$ & & \\
\hline
\end{tabular}




\begin{tabular}{|c|c|c|}
\hline $\begin{array}{l}Q Q_{c t}=\sum_{h} Q H_{c, h t}+H I N V_{c t}+G D C_{c t}+G D I_{c t} \\
+Q I N V_{c t}+\sum_{a} Q I N T_{c, a t}+d s t_{c t}\end{array}$ & $\begin{array}{l}\text { Total demand } \\
=\text { composite supply }\end{array}$ & 50 \\
\hline $\begin{array}{l}\sum_{c} p w m_{c t} \cdot Q M_{c t}=\sum_{c} p w e_{c t} \cdot Q E_{c t}+ \\
\overline{R E M I T_{t}}+\overline{F S A V}_{t}+\overline{G F B O R_{t}}\end{array}$ & Current account & 51 \\
\hline$K_{a t+1}=K_{a t}\left(1-d e p_{a}\right)+D K_{a t}$ & $\begin{array}{l}\text { Dynamics of } \\
\text { sectoral capital } \\
\text { stock }\end{array}$ & 52 \\
\hline$L S_{t+1}=L S_{t}(1+n)$ & $\begin{array}{l}\text { Labor supply } \\
\text { specification }\end{array}$ & 53 \\
\hline$Z_{a t+1}=Z_{a t}+t g t_{t}+\overline{R A N D O M}_{a t+1}$ & $\begin{array}{l}\text { Technology } \\
\text { specification }\end{array}$ & 54 \\
\hline
\end{tabular}

\begin{tabular}{|c|c|c|c|}
\hline \multicolumn{4}{|c|}{ Variables and Parameters } \\
\hline$n$ & $\begin{array}{l}\text { growth rate of labor } \\
\text { supply }\end{array}$ & gtar $_{t}$ & $\begin{array}{l}\text { the share of non interest } \\
\text { expenditures as a share } \\
\text { of GDP }\end{array}$ \\
\hline $\operatorname{tgt}_{t}$ & $\begin{array}{l}\text { growth rate of } \\
\text { technology }\end{array}$ & $\overline{G I N T P}_{t}$ & $\begin{array}{l}\text { government interest } \\
\text { payments }\end{array}$ \\
\hline$\overline{\text { RANDOM }}_{a t+1}$ & $\begin{array}{l}\text { random technology } \\
\text { shocks }\end{array}$ & & \\
\hline
\end{tabular}

\section{Model Data}

The model extensively uses the SAM constructed Aslan (2004) in the calibration process. The other sectoral data is portrayed on Table 6. In order to calculate the capital stock for the base year, we employ growth accounting method. After calculating the share parameters for labor $\left(\alpha_{a}\right)$ and capital, the data for investment by sector of destination $\left(\Delta K_{a}\right)$, increment in employment by each sector $\left(n_{\cdot_{a}}\right)$, sectoral growth rate $\left(\Delta Q_{a}\right.$ ) are gathered from SPO data base. Moreover, $1.1 \%$ total factor productivity growth $\left(\triangle T F P_{a}\right)$ and $5 \%$ depreciation rate $\left(\delta_{a}\right)$ are assumed. Using the growth accounting equation i.e. equation Eq-A-1, the stock of capital for each sector is calculated. 


$$
\Delta Q_{a}=\Delta \operatorname{TFP}_{a}+n_{\cdot a} \cdot \alpha_{a}+\left(1-\alpha_{a}\right) \cdot \frac{\Delta K_{a}}{K_{a}\left(1-\delta_{a}\right)}
$$

In order to estimate the statistical relation between the public sector borrowing requirement to GNP ratio and capacity utilization, simple OLS regression is employed. The result of the regression is portrayed on EqA-2 where numbers in the parenthesis indicate the t-Statistics.

$$
\begin{array}{cll}
C U_{t}=2601-1.264 .\left(P S B R_{t} / C P I_{t}\right) & R^{2}=0.623 \\
(3.24) & (-3.151) & T=1996-2002
\end{array}
$$

The increase (decrease) in real value of PSBR is used as proxy for government's self-discipline in delivering sound fiscal policy and this data is used as independent variable in the regression.

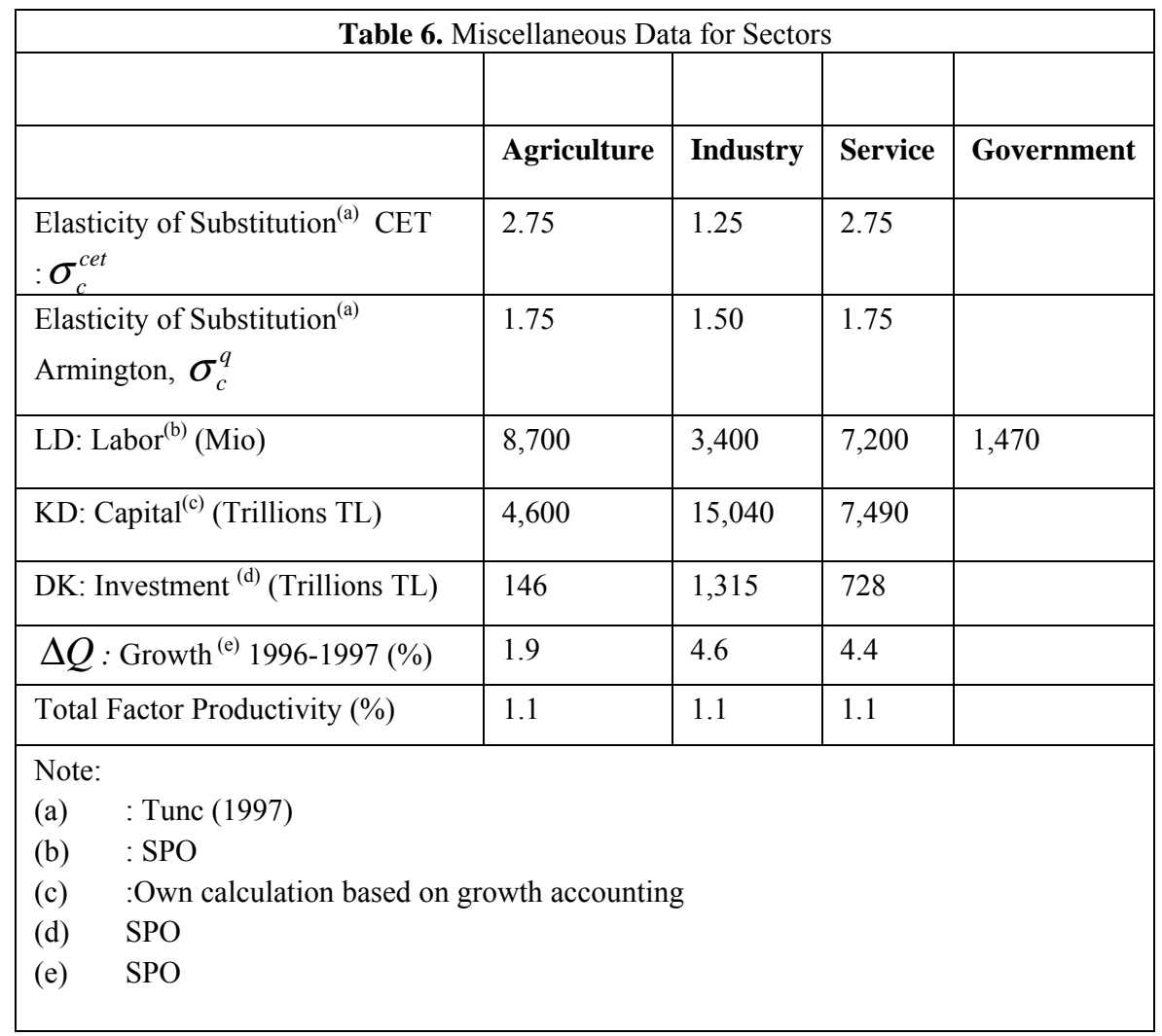

